\title{
S13 Fig
}

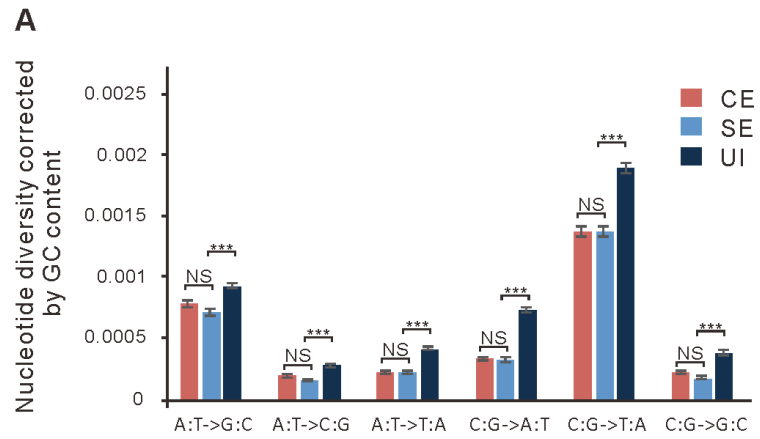

B

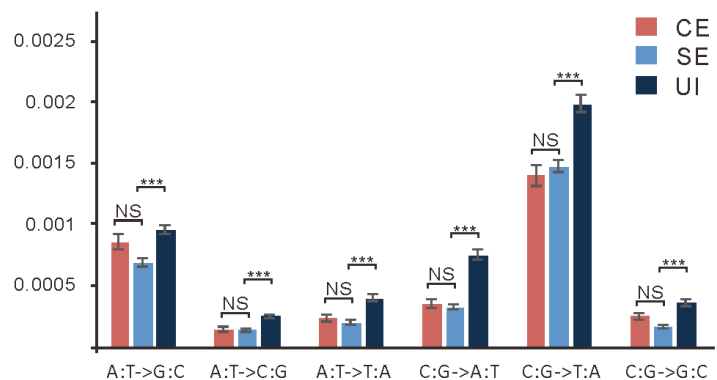

c

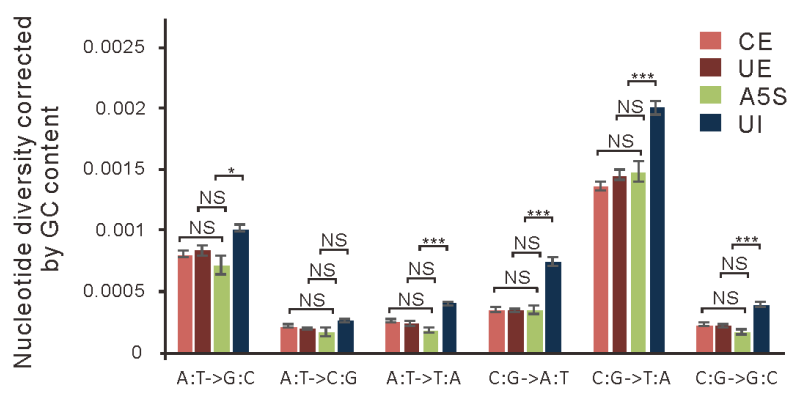

D

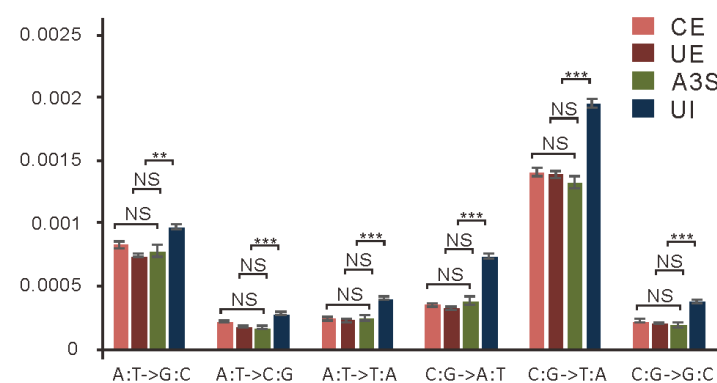

E

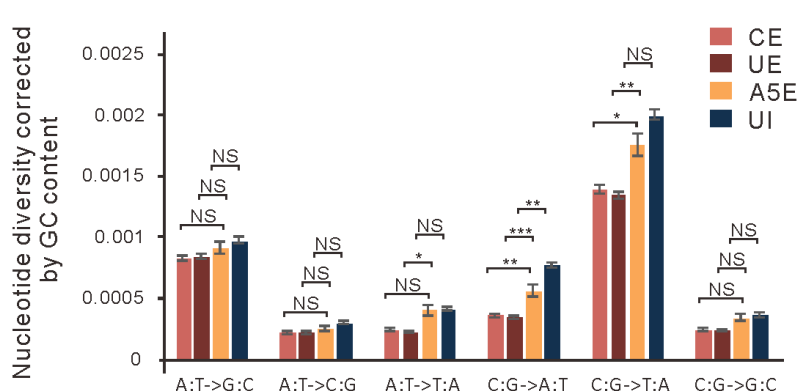

F

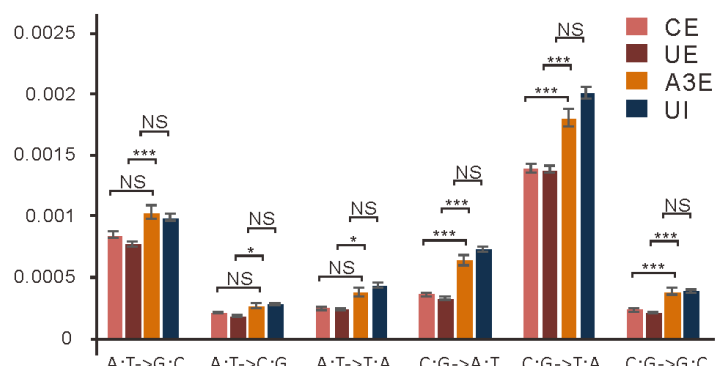

